\title{
Changes in $\alpha$-estradiol receptor and progesterone receptor expression in the locus coeruleus and preoptic area throughout the rat estrous cycle
}

\author{
Cleyde Vanessa Vega Helena ${ }^{1}$, Maristela de Oliveira Poletini ${ }^{1}$, \\ Gilberto Luiz Sanvitto ${ }^{3}$, Shinji Hayashi ${ }^{4}$, Celso Rodrigues Franci ${ }^{1}$ \\ and Janete Aparecida Anselmo-Franci ${ }^{2}$ \\ ${ }^{1}$ Departamento de Fisiologia, Faculdade de Medicina de Ribeirão Preto-Universidade de São Paulo, Ribeirão Preto, Brazil \\ ${ }^{2}$ Laboratório de Neuroendocrinologia, Faculdade de Odontologia de Ribeirão Preto-Universidade de São Paulo, Ribeirão Preto, Brazil \\ ${ }^{3}$ Laboratório de Neuroendocrinologia do Comportamento, Departamento de Fisiologia da Universidade Federal do Rio Grande do Sul, Porto Alegre, Brazil \\ ${ }^{4}$ Laboratory of Endocrinology, Graduate School of Integrated Science, Yokohama City University, Yokohama, Japan \\ (Requests for offprints should be addressed to JA Anselmo-Franci, Faculdade de Odontologia de Ribeirão Preto - Universidade de São Paulo, Avenida do café, \\ Ribeirão Preto, São Paulo 14040-904, Brazil; Email: jaafranc@usp.br)
}

\begin{abstract}
We have previously shown that the locus coeruleus (LC) is essential for triggering surges of LH. Since LC neurons are responsive to estradiol, which induces progesterone receptor (PR) expression, this study aimed to investigate whether LC neurons express the $\alpha$-estradiol receptor $(\alpha E R)$ and PR as well as comparing such responses to that observed in the preoptic area (POA). Female rats were perfused at 10,14 and $16 \mathrm{~h}$ on each day of the estrous cycle, and a blood sample was collected for estradiol, progesterone and LH measurements. $\alpha E R-$ and PR immunoreactive (ir) neurons were detected in POA and LC by immunocytochemistry (ICC). Higher plasma estradiol levels were observed on the day of proestrus, when a smaller number of $\alpha E R$-ir POA neurons were detected. An increase in the number of $\alpha E R$-ir neurons were observed at $16 \mathrm{~h}$ of proestrus and estrus. The number of PR-ir neurons increased in POA only at $16 \mathrm{~h}$ of proestrus, and remained unchanged during all other days
\end{abstract}

and times. The profile of $\alpha E R$-ir and PR-ir neurons in LC changed over the estrous cycle, with a lower expression on metestrus morning and reaching a peak on diestrus afternoon before declining on the day of proestrus. However, on estrus afternoon, $\alpha E R$-ir neurons increased, while PR-ir neurons decreased which may be related to the prolactin surge of estrus. These data show that LC neurons express $\alpha E R$ and PR and seem to be more sensitive to variations in estradiol than POA. Also, the fluctuation in $\alpha \mathrm{ER}$ and PR observed for LC neurons seems to accompany the hormonal events that occur during the estrous cycle. This profile of $\alpha E R$ and PR expression might be related to the ability of estradiol and progesterone in regulating the activity of LC neurons, which could be associated to the control mechanisms of LH and prolactin release.

Journal of Endocrinology (2006) 188, 155-165

\section{Introduction}

Luteinizing hormone (LH) secretion is under control of the gonadotropin releasing hormone $(\mathrm{GnRH})$, which in rodents, is mainly produced by the preoptic area (POA) neurons and is released at terminals of the median eminence (Levine \& Ramirez 1982, Park \& Ramirez 1989). Although it is well known that ovarian steroids control $\mathrm{GnRH}$ and LH secretion, the precise sites where estradiol and progesterone exert such control are not clear.

Two isoforms of the estradiol receptor (ER) have been described: $\alpha E R$ and $\beta E R$ (Kuiper et al. 1996). Since $\alpha E R$ knockout mice are completely infertile and $\beta E R$ knockout mice show only a decreased fecundation rate
(Lubahn et al. 1993), it seems that the activation of $\alpha$ ERs is more strictly related to the regulation of reproductive events. However, although the presence of $\alpha E R$ has been reported in 20\% of GnRH neurons in ovariectomized rats treated with colchicine (Butler et al. 1999), most authors have demonstrated that GnRH neurons do not express aER (Herbison \& Theodosis 1992, Herbison et al. 1995, Laflamme et al. 1998, Herbison \& Pape 2001). These data suggest that estradiol may control GnRH indirectly via $\alpha E R-s e n s i t i v e ~ n e u r o n s$ which project to GnRH neurons located inside or outside POA (Herbison 1998).

Furthermore, one of the main effects of estradiol in the central nervous system (CNS) is the induction of progesterone receptor (PR) expression (MacLusky \& McEwen 1978). 
PR activation seems to be a critical step in the full-length generation of the preovulatory LH surge, since progesterone administration to estradiol-primed ovariectomized rats results in the amplification and anticipation of $\mathrm{GnRH}$ (Levine \& Ramirez 1980) and LH (Everett 1948, Krey et al. 1973) surges, and administration of PR antagonist RU486 to proestrus rats blocks LH surge (Bauer-Dantoin et al. 1993). Also, PR knockout mice are anovulatory and fail to show an LH surge when exposed to male odors (Chappell et al. 1997). Since most GnRH neurons do not contain PRs (Fox et al. 1990), progesterone, like estradiol, may indirectly influence the activity of GnRH neurons.

Noradrenaline is known to be one of the excitatory neurotransmitters for LH release (Tima \& Flerko 1974, Kalra 1985, Osterburg et al. 1987). Locus coeruleus (LC) is the major noradrenergic nucleus and sends projections to the entire CNS, including areas involved in $\mathrm{GnRH}$ synthesis and secretion (Swanson \& Hartman 1975, Foote et al. 1983, Wright \& Jennes 1993). Data from our laboratory have demonstrated that electrolytic lesion of LC decreases noradrenaline content in medial POA and medial basal hypothalamus and blocks the preovulatory gonadotropin surges observed during proestrus as well as LH pulses (Anselmo-Franci et al. 1999) and the steroidinduced surge in ovariectomized rats by decreasing GnRH release (Franci \& Antunes-Rodrigues 1985, Anselmo-Franci et al. 1997, 1999, Helena et al. 2002, Martins-Afferri et al. 2003). Also, an increased number of FOS-immunoreactive (FOS-ir) neurons was observed in LC simultaneously with the preovulatory gonadotropin surges (Martins-Afferri et al. 2003).

Since LC neurons concentrate estradiol (Heritage et al. 1980), express mRNA for ER (Shughrue et al. 1997) and PR (Curran-Rauhut \& Petersen 2002), and are responsive to estradiol treatment, increasing the expression of noradrenaline synthetic enzymes (Serova et al. 2002), it is likely that LC neurons are a target for estradiol action, as described for noradrenergic neurons A1 and A2 (Haywood et al. 1999). If so, LC neurons should express ER and, consequently, PR. Therefore, this study aimed at investigating whether LC neurons express $\alpha \mathrm{ER}$ and PR and whether changes in these expressions occur during the estrous cycle as well as at comparing such pattern to that observed in the POA.

\section{Materials and Methods}

\section{Animals}

Adult female Wistar rats weighing 250-300 g were housed in collective cages (5 per cage) under controlled temperature $\left(24 \pm 0.5^{\circ} \mathrm{C}\right)$ and light conditions (lights on from 6:00 to $18: 00 \mathrm{~h}$ ). Food and water were supplied ad libtum. Only rats showing at least three consecutive regular 4-day estrous cycles were included in this study. In addition, the proestrus group studied at 16:00 h only included rats that exhibited $\mathrm{LH}$ levels higher than $3 \mathrm{ng} / \mathrm{ml}$, which indicates the occurrence of a preovulatory surge, since basal LH levels generally do not exceed $1 \cdot 0 \mathrm{ng} / \mathrm{ml}$.

\section{Tissue preparation}

The animals were anesthetized with 2,2,2-tribromoethanol $(250 \mathrm{mg} / \mathrm{kg}$ body weight; i.p.; Aldrich Chemical Co. Inc., Milwaukee, WI, USA) and perfused at 10:00, 14:00 and 16:00 h of each day of the estrous cycle $(n=6-8$ per group). Transcardial perfusion was performed with $50 \mathrm{ml}$ 0.01 M phosphate buffered saline (PBS), $\mathrm{pH} 7 \cdot 4$, containing $5 \mathrm{IU} / \mathrm{ml}$ heparin, immediately followed by $300 \mathrm{ml}$ ice-cold $4 \%$ paraformaldehyde in $0 \cdot 1 \mathrm{M}$ phosphate buffer (4\% PFA). The brains were quickly removed, postfixed in 4\% PFA for $2 \mathrm{~h}$, and cryoprotected in 30\% sucrose in $0.1 \mathrm{M}$ phosphate buffer at $4{ }^{\circ} \mathrm{C}$, where they were kept until sinking (approximately $48 \mathrm{~h}$ ). The fixed brains were frozen by immersion in iso-pentane (Riedel-de Haën, Seelze, Germany) at $-40{ }^{\circ} \mathrm{C}$ for one minute and frontal serial $30 \mu \mathrm{m}$ sections were cut with a cryostat throughout the rostrocaudal extension of LC and POA between 0.26-1.30 mm post Bregma for POA limits and between $9 \cdot 16-10 \cdot 52 \mathrm{~mm}$ post Bregma for LC neuron limits according to the Paxinos atlas (Paxinos \& Watson 1998). They were stored in a cryoprotectant solution (Watson et al. 1986) at $-20^{\circ} \mathrm{C}$ until processed.

\section{Antibody specificity}

The antiserum recognizing $\alpha$ ER (AS 409; Okamura et al. 1992) was raised in a rabbit against the conjugated protein of beta galactosidese-rat $\alpha E R$, which was produced in $E$. coli cells containing rat $\alpha \mathrm{ER}$ cDNA (for a detailed description, see (Okamura et al. 1992)). The antibody recognizes bound and unbound $\alpha \mathrm{ER}$ (Okamura et al. $1992)$ and preadsorption with $\alpha E R$ protein results in no immunolabeling (Papka et al. 1997, Weiland et al. 1997). For PR ICC, we used a polyclonal antibody directed against the DNA-binding domain (B region) of human PR (Host: rabbit, A0098, DAKO Corp., Carpinteria, CA, USA). This antibody shows similar reactivity to that of the monoclonal antibody, clone PR AT $4 \cdot 14$, and recognizes a specific site in the unactivated and activated PR and distinguishes between intact and proteolyzed receptors (Traish \& Wotiz 1990). The specificity of the PR antibody was determined by incubating control sections from animals perfused in the afternoon of metestrus and diestrus with an anti-PR that had been previously preabsorbed overnight at $4{ }^{\circ} \mathrm{C}$ with $200 \mu \mathrm{g} / \mathrm{ml}$ of the antigen peptide (amino acids 533-547; Alpha Diagnostic International Inc, TX, USA), which eliminated nuclear labeling throughout the preoptic area and locus coeruleus. For tyrosine hydroxylase (TH) staining, we used a monoclonal TH antibody (Host: mouse, anti $\mathrm{TH}-2$; 
Sigma Chemical Co.). The antibody recognizes an epitope present in the $\mathrm{N}$-terminal region (approximately amino acids 9-16) of both rodent and human TH. Clone TH-2 reacts with the intact $\mathrm{TH}$ subunits. No nuclear labeling was observed when $\alpha E R$ or PR primary antibodies were replaced with PBS containing 0.3\% TX-100 and $1 \%$ bovine serum albumin (BSA), indicating the specificity of the antibodies for these proteins (data not shown). No cytoplasm immunoreactivity was detected for the TH antibody by using the same procedure.

\section{Double-labelling immunocytochemistry}

Every first and second section from sets of four sections was used for immunocytochemistry (ICC) of $\alpha E R$ and PR, respectively. All ICC steps were performed at $22{ }^{\circ} \mathrm{C}$, except for incubation with the primary antibodies, which was performed at $4{ }^{\circ} \mathrm{C}$. Free-floating sections were placed on culture dishes and rinsed five times in PBS to wash out the cryoprotectant. Immediately thereafter, the sections were rinsed in $0 \cdot 1 \mathrm{M}$ glycine in PBS, incubated with $0.3 \%$ Triton X-100 (TX-100) in PBS for $30 \mathrm{~min}$, followed by incubation with $1 \% \mathrm{H}_{2} \mathrm{O}_{2}$ in PBS for $1 \mathrm{~h}$ and, finally, with $3 \% \mathrm{BSA}$ in PBS for $1 \mathrm{~h}$. The first series of sections was then incubated with anti- $\alpha$ ER (AS 409) at a dilution of 1:10 000 in PBS containing 0.3\% TX-100 and 1\% BSA for $40 \mathrm{~h}$ (all primary and secondary antibodies were diluted in the same buffer). The second series of sections was incubated with anti-PR antibody at 1:250 dilution for $70 \mathrm{~h}$. After washing with PBS, all sections were incubated with biotinylated anti-rabbit IgG (Host: goat, Elite kit, Vector Laboratories, Burlingame, CA, USA) at 1:400 dilution for $\alpha E R$ and $P R$, for $2 \mathrm{~h}$, and with the avidin DH-biotinylated horseradish peroxidase complex (ABC at 1:100 in PBS for each A and B Elite kit reagents, Vector Laboratories) for $1 \mathrm{~h}$. The final reaction was carried out using a solution containing 3, $3^{\prime}$-diaminobenzidine- $\mathrm{HCl}$ $\left(0 \cdot 2 \mathrm{mg} / \mathrm{ml} \mathrm{DAB}\right.$; Sigma) and $\mathrm{H}_{2} \mathrm{O}_{2}(1 \mu \mathrm{L} / \mathrm{ml}$ from a $30 \%$ solution) with nickel chloride $(25 \mathrm{mg} / \mathrm{ml})$ in PBS. After washing with PBS and $1 \% \mathrm{H}_{2} \mathrm{O}_{2}$ in PBS for $15 \mathrm{~min}$, the LC-containing sections were incubated with the $\mathrm{TH}$ antibody at 1:30 000 for $40 \mathrm{~h}$. After washing with PBS, the sections were incubated for $1 \mathrm{~h}$ with a biotinylated horse anti-mouse secondary antibody (1:1000). After washing in PBS, the tissues were incubated for $30 \mathrm{~min}$ with $\mathrm{ABC}$, washed again with $\mathrm{PBS}$ and developed using DAB $(0 \cdot 1 \mathrm{mg} / \mathrm{ml})$ plus $1 \mu \mathrm{L} / \mathrm{ml}_{2} \mathrm{H}_{2}$ from a $30 \%$ solution in $0.05 \mathrm{M}$ Tris- $\mathrm{HCl}$ buffer, $\mathrm{pH} 7.6$ (Shu et al. 1988). Sections were mounted on gelatin-coated glass slides, air-dried, rinsed in ethanol, cleared in xylene and coverslipped with Entellan (Entellan, Merck).

\section{Analysis}

The sections were blindly examined under a light microscope (Axioskop 2 plus, Zeiss, Hallbergmoos, Germany) using an image analysis system (Axiovision $3 \cdot 1$, Zeiss). The number of $\alpha E R-i r$ and PR-ir neurons was counted unilaterally (right side) in a total of 6 POA sections and 8 LC sections per animal, at a magnification of $\times 200$. The LC sections were grouped in accordance to the morphology previously described (Grzanna \& Molliver 1980). $\alpha E R$-ir and PR-ir neurons of LC were counted in 2 sections from the rostral portion and 6 from the LC proper using $\mathrm{TH}$ immunostaining to identify the precise boundaries of the LC region. The number of $\alpha \mathrm{ER}$-ir and $\mathrm{PR}$-ir neurons in the POA was quantified in 6 sections beginning in the most rostral region of POA (AVPV) until the medial POA, in an area measuring $400 \times 400 \mu \mathrm{m}$ using the third ventricle as the medial limit. The results are expressed as the average of the total number of $\alpha E R$-ir or PR-ir neurons in all counted sections for each rat.

\section{Blood samples}

One minute before the beginning of perfusion, $1 \mathrm{ml}$ blood samples were collected from the right ventricle of anesthetized rats into heparinized syringes, centrifuged at $1200 \boldsymbol{g}$ for $15 \mathrm{~min}$ at $4{ }^{\circ} \mathrm{C}$, and plasma was separated and stored at $-20{ }^{\circ} \mathrm{C}$ until the time for RIA. Plasma LH concentrations were determined using specific kits provided by the Institute of Diabetes and Digestive and Kidney Diseases (NIDDK, Baltimore, MD, USA). The antiserum for LH was LH-S10 and the reference preparation was RP3. The lower limit of detection was $0 \cdot 2 \mathrm{ng} / \mathrm{ml}$ and the intra-assay coefficient of variation was 4\%. Plasma estradiol and progesterone concentrations were determined using the Estradiol and Progesterone Maia kits (Biochem Immunosystems, Serotec, Italy), respectively. The lower detection limit and the intra-assay coefficient of variation were respectively $7.5 \mathrm{pg} / \mathrm{ml}$ and $2.5 \%$ for estradiol and $4.1 \mathrm{ng} / \mathrm{ml}$ and $3.7 \%$ for progesterone. All samples were measured in duplicate and at different dilutions, if necessary. In order to prevent interassay variation, all samples were assayed in the same RIA.

\section{Statistical analysis}

The influence of the estrous cycle phases on the number of $\alpha$ ER-ir and PR-ir neurons in LC and POA was assessed by two-way ANOVA. When the $F$ values indicated significant differences, post hoc comparisons were made between groups using one-way ANOVA followed by the Newman-Keuls test for multiple comparisons. Values were considered to be significant when $P<0 \cdot 05$.

\section{Results}

Figure 1 shows a schematic drawing depicting the region of LC (A) and POA (B) where $\alpha E R$-ir and PR-ir neurons 

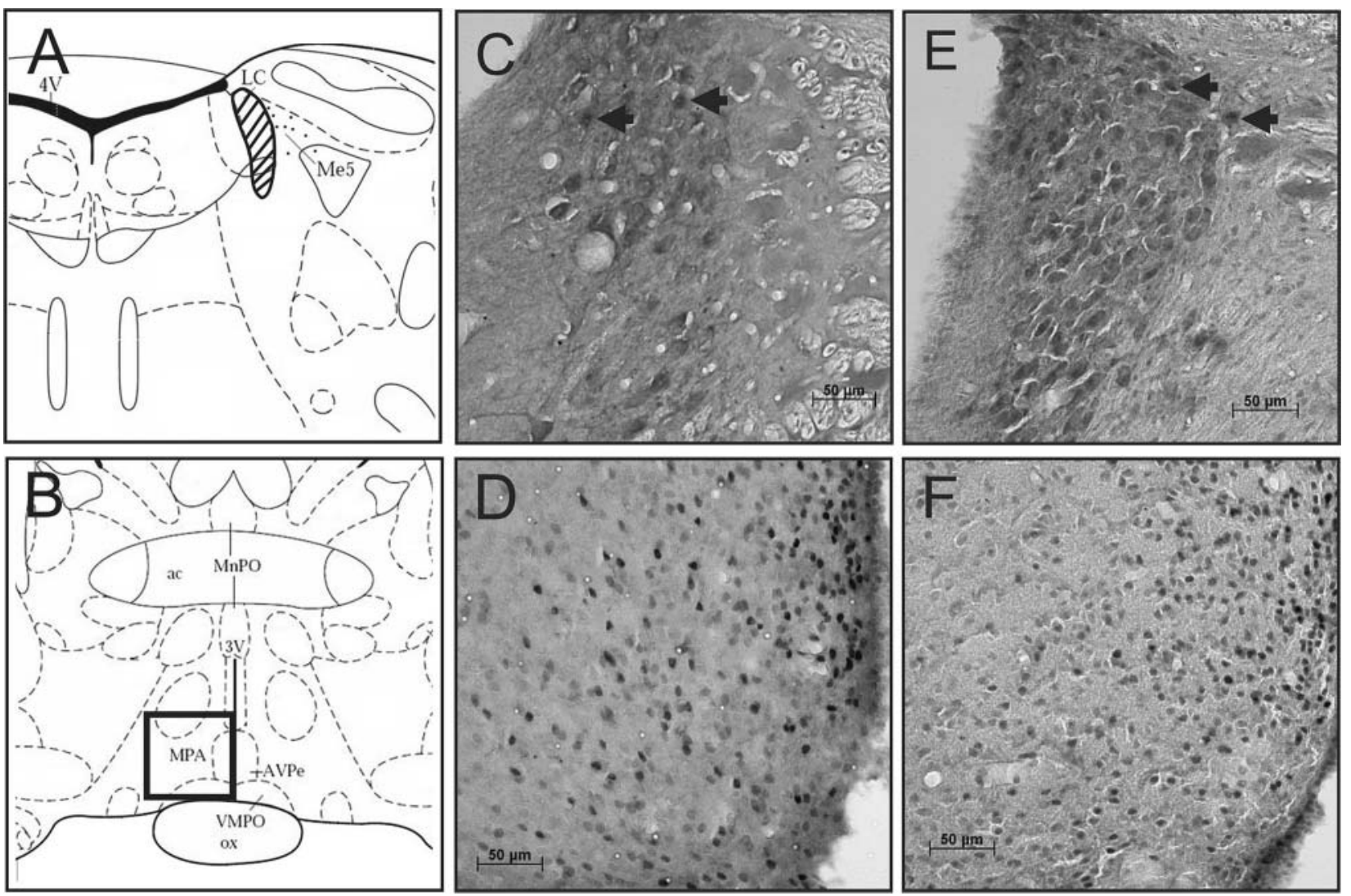

Figure 1 Schematic view of the locus coeruleus (LC; hatched area in $\mathrm{A}$ ) and preoptic area (POA; box in B), and photomicrographs of $\alpha$ ER (C, D)- and PR (E, F)-immunoreactive neurons in LC (C, E) and POA (D, F) of a female rat perfused at 16:00 h of diestrus. In LC, all $\alpha$ ERand PR-immunoreactive neurons were colocalized with tyrosine hydroxylase (arrows). The box in B shows the selected area used for quantification.

were evaluated as well as $\alpha \mathrm{ER}$-ir and PR-ir neurons in LC (C and E) and POA (D and F) as examples. Since most LC neurons express TH (Pickel et al. 1975), immunostaining (only seen in the neuronal cytoplasm) was efficient in delimiting the LC boundaries, as shown in panels $\mathrm{C}$ and $\mathrm{E}$. In LC, $\alpha$ ER-ir and PR-ir neurons were always colocalized with $\mathrm{TH}$, but not all $\mathrm{TH}$-ir neurons were positive for both receptors. Moreover, the number of PR-ir neurons was much larger than that of $\alpha E R-i r$ neurons, not only in the LC but also in the POA region. No PR labeling was found in the TH-expressing cells of the LC and in POA region when anti-PR was preabsorbed with the antigen peptide, indicating specificity of this antibody to detect PR in these regions, as it is shown in Fig. 2.

Regarding the days of the estrous cycle, the profile of $\alpha$ ER-ir and PR-ir cells in LC changed in a similar way over the estrous cycle, as we can observe by the curves superimposed to the bars in Figures $3 \mathrm{~A}$ and 3C. The expression of both receptors increased gradually from a lower expression on metestrus morning and reached its maximum level on diestrus afternoon $(P<0 \cdot 01$ and
$P<0 \cdot 001$, respectively), before declining on proestrus day. However, on estrus afternoon, the number of $\alpha E R-i r$ neurons increased $(P<0 \cdot 001)$, while that of PR-ir neurons decreased $(P<0 \cdot 05)$. As expected, the highest plasma estradiol levels during the estrous cycle were observed during all times of proestrus day $(P<0 \cdot 001)$ while they were lower and constant on all other days and times studied (Fig. 3B). Progesterone levels were higher on metestrus $(P<0 \cdot 05)$, decreased on diestrus and tended to increase on proestrus afternoon (Fig. 3D). These variations occurred in an opposite direction from that of $\mathrm{PR}$ expression in LC (Fig. 3C). Basal LH concentrations were observed during all times, except at 16:00 $\mathrm{h}$ of proestrus (time of the preovulatory surge, $P<0 \cdot 01$ ), as shown in Fig. 3E.

In contrast to LC, a constant number of $\alpha$ ER-ir cells was found in the POA (Fig. 4A) over the days of the estrous cycle, except on proestrus day when a decrease in this number was observed $(P<0 \cdot 001)$. Concerning the times studied, the number of $\alpha E R$-ir cells did not differ among them on metestrus and diestrus days, whose values were similar to those observed at 10:00 and 14:00 h 

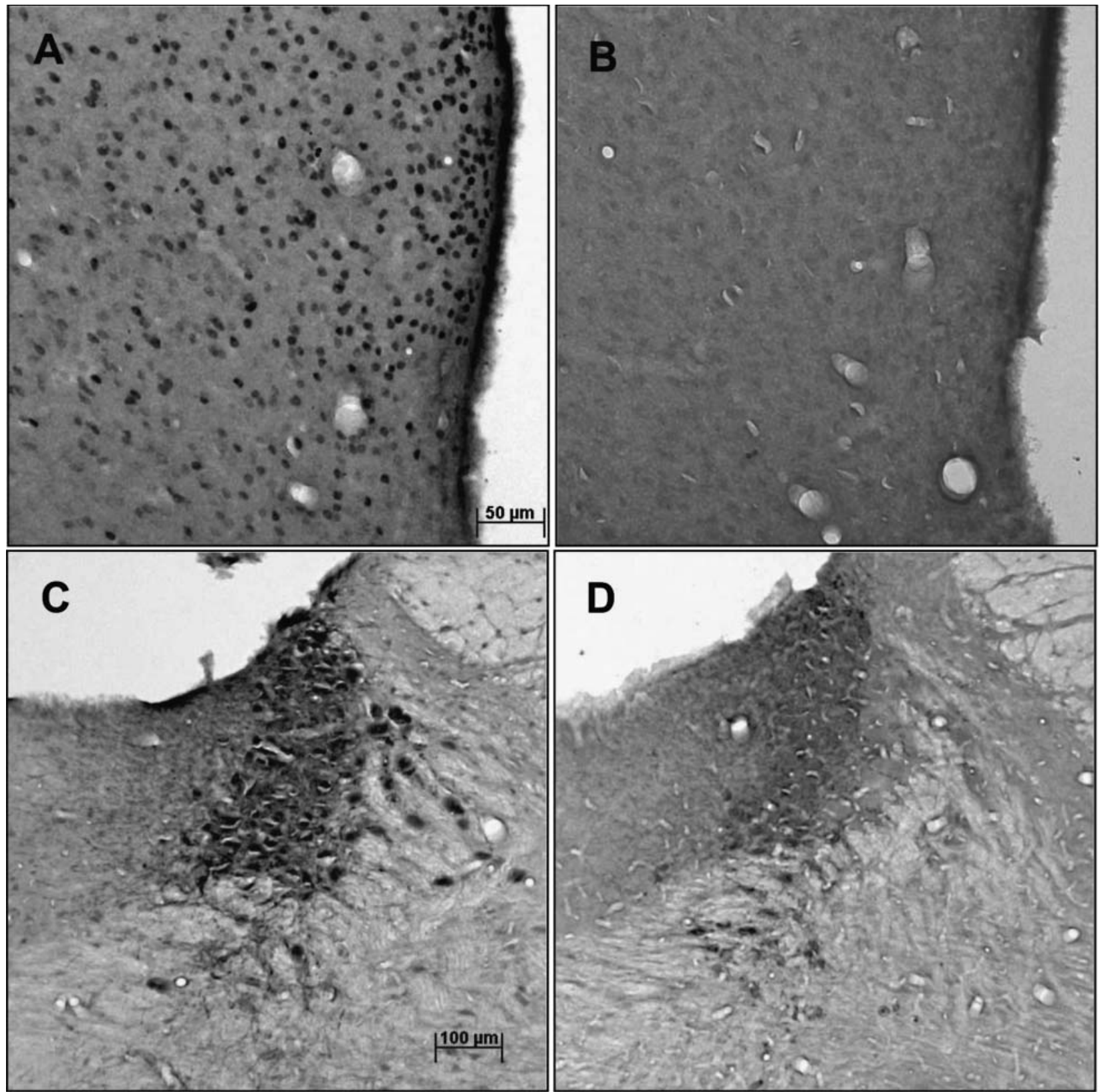

Figure 2 Photomicrographs of PR-immunoreactive neurons in POA (A and B) and LC (C and D) illustrating the preabsorption test. Sections from rats perfused in the afternoon of diestrus were incubated with the anti-PR alone (A and C) or with an anti-PR that has been pre-absorbed overnight with the antigen peptide (B and D). The pre-absorption completely abolished nuclear staining of PR in both areas, while TH immunoreactivity persisted in the cytoplasm of the LC neurons.

on estrus day. However, there was an increase in the number of $\alpha$ ER-ir cells at $16: 00 \mathrm{~h}$ on proestrus and estrus day $(P<0 \cdot 05$ and $P<0 \cdot 01)$ as compared with the other times studied. The number of PR-ir cells did not vary in POA (Fig. 4B), except at 16:00 $\mathrm{h}$ of proestrus, when a significant increase was observed $(P<0 \cdot 01)$.

\section{Discussion}

In the present study, we described the presence of $\alpha E R$ and PR in LC neurons of female rats as well as their pattern of expression during the estrous cycle by comparing it to that observed in POA. Expression of $\alpha$ ER in LC 


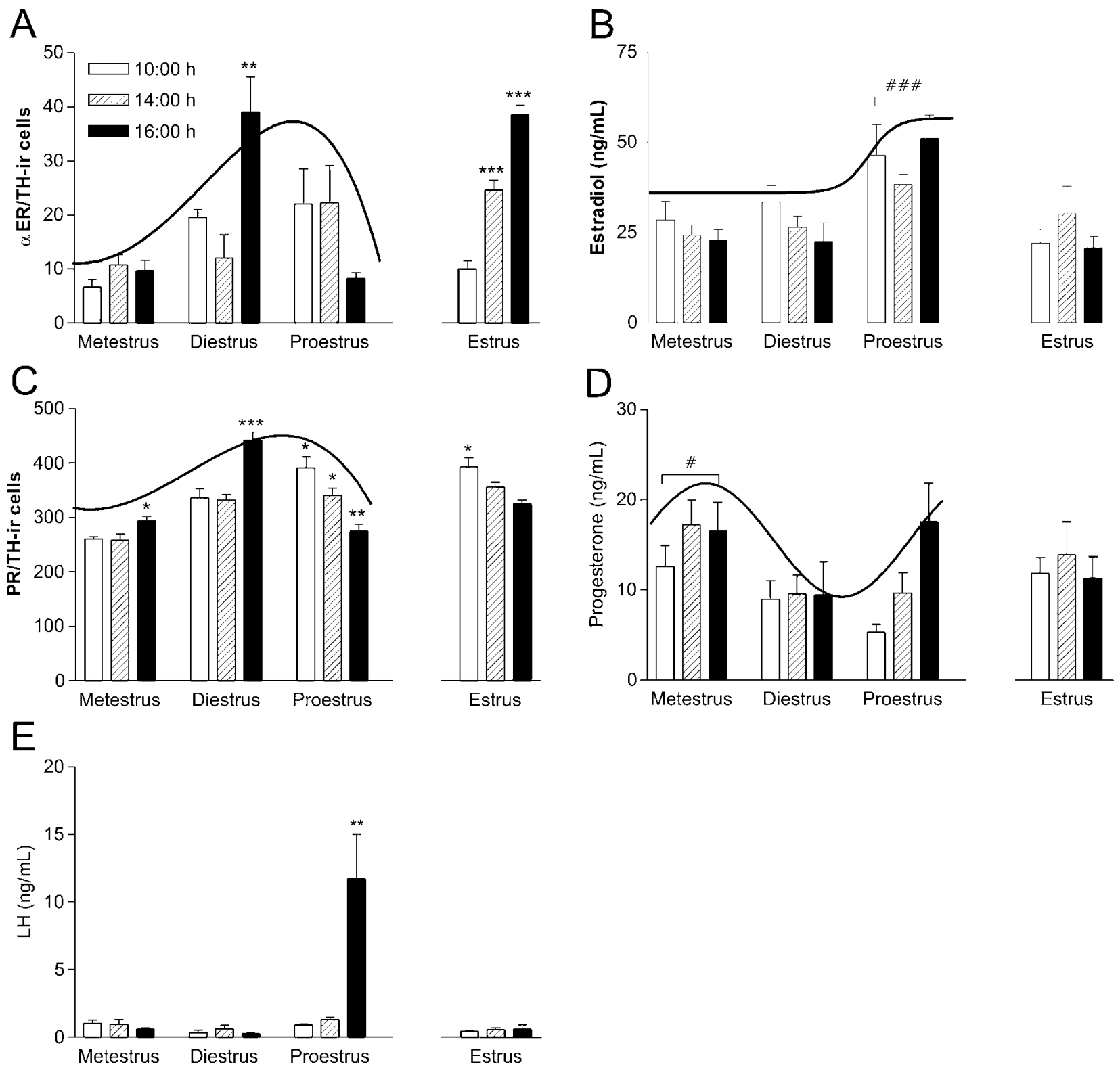

Figure 3 Number of $\alpha E R$ and PR-immunoreactive (ir) neurons in LC (A and C, respectively), plasma estradiol (B), progesterone (D) and $\mathrm{LH}$ (E) concentrations of cycling female rats on each day of the estrous cycle. $\# P<0 \cdot 05$ and $\# \# \# P<0 \cdot 001$ compared with other days of the estrous cycle; ${ }^{*} P<0 \cdot 05,{ }^{*} P<0 \cdot 01$ and ${ }^{* *} P<0 \cdot 001$ compared with the other times in the same group $(n=6-8)$.

has previously been described for male mice (Mitra et al. 2003), while no data regarding the expression of PR in this nucleus are available thus far. Although we did not colocalize $\alpha E R$ and PR, it is possible that PR was expressed in $\alpha \mathrm{ER}$-positive neurons since some studies conducted on guinea pigs support the hypothesis that estradiol-inducible PRs occur only in cells expressing ERs (Blaustein \& Turcotte 1989, Warembourg et al. 1989). Interestingly, we found that the number of PR-ir cells was much larger than that of $\alpha \mathrm{ER}$-ir cells in LC and POA in all groups studied. Thus, if PR-positive neurons should also express ER, it is possible that PR synthesis was induced by an ER other than $\alpha E R$. In fact, disruption of the $\alpha E R$ gene suppressed, but did not completely inhibit, the induction of $\mathrm{PR}$ in several brain regions, including POA, of $\alpha E R-k n o c k o u t$ mice (Moffatt et al. 1998). This suggests that the induction of PR in $\alpha E R-k n o c k o u t$ mice may also be mediated by $\beta E R$. In this regard, it has been 

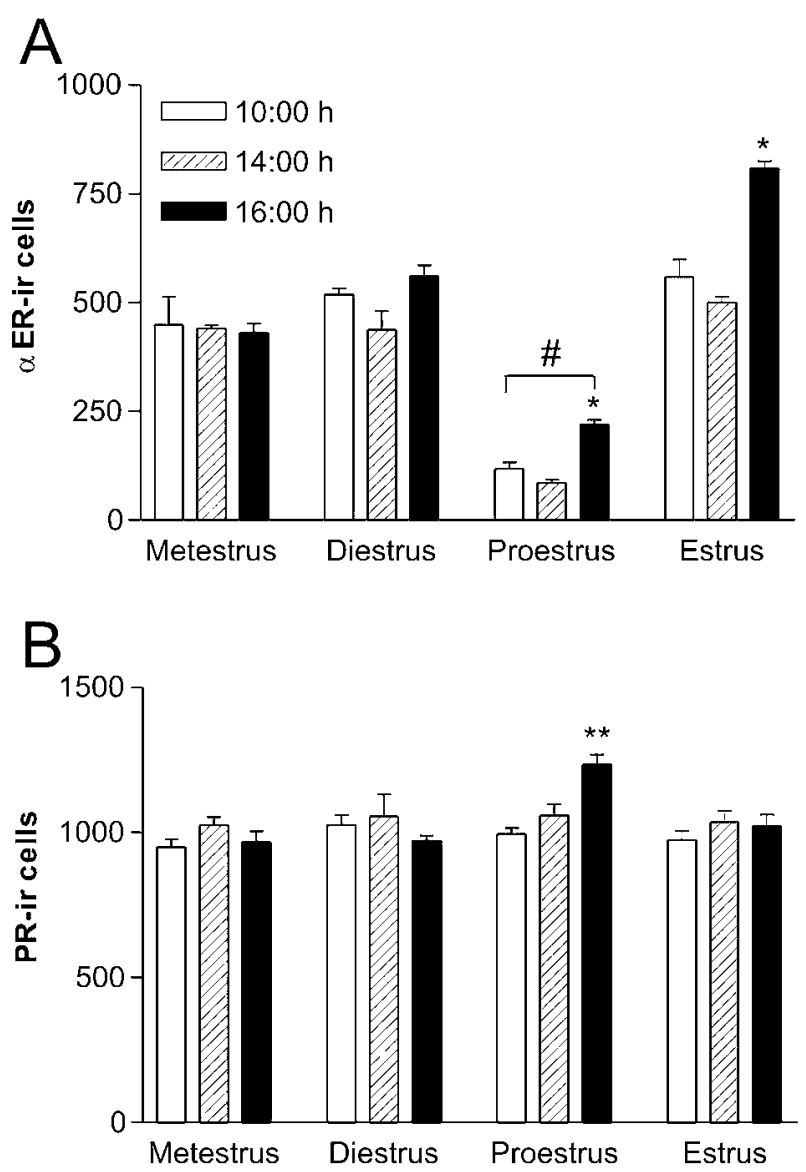

Figure 4 Number of $\alpha E R$ and PR-immunoreactive (ir) neurons in POA ( $A$ and $B$, respectively) in cycling female rats on each day of the estrous cycle. $\# P<0.05$ compared with other days of the estrous cycle; ${ }^{*} P<0.05$ and ${ }^{*} P<0.01$ compared with the other times in the same group $(n=6-8)$.

demonstrated that POA and LC neurons express $\beta E R$ mRNA (Shughrue et al. 1997b) and that the two receptors $(\alpha E R$ and $\beta E R)$ bind to estradiol with equal affinity (Kuiper et al. 1997). In addition, $\beta E R$ has been shown to be expressed in $\alpha E R$ - and PR- containing cells in the female rat forebrain (Greco et al. 2001). Thus, although it is not known whether $\beta E R$ induces PR synthesis, this could be a possibility to explain the larger number of $\mathrm{PR}$-ir cells (when compared with $\alpha E R$-ir cells) found in LC and POA neurons.

\section{Locus Coeruleus}

From metestrus to proestrus The profile of expression of $\alpha E R$-ir and PR-ir in the LC neurons changed significantly during the estrous cycle. Although basal estradiol levels were observed on metestrus and diestrus days, the expression of both receptors was lower on metestrus and increased gradually until reaching its maximum level at $16 \mathrm{~h}$ of diestrus afternoon. Increased levels of estradiol are required to activate the $\mathrm{LH}$ surge on proestrus afternoon since administration of estradiol inhibitors (Shirley et al. 1968) and estradiol antiserum (Neill et al. 1971) on diestrus blocks the proestrus LH surge. In this regard, this increase in the number of $\alpha E R$-ir cells in LC may be a way to prepare this nucleus to respond to the increase of estradiol levels which starts in the late evening of diestrus (Smith et al. 1975) in order to activate the LH surge on proestrus afternoon, which was observed at $16 \mathrm{~h}$ in our study.

On proestrus day, when the highest levels of estradiol were observed, there was a decreased number of $\alpha E R$-ir cells in LC at all times studied, when compared with $16 \mathrm{~h}$ of diestrus, which may suggest that $\alpha \mathrm{ER}$ synthesis was down-regulated by estradiol. In fact, although estradiol has been demonstrated to induce an increase in its own receptors in peripheral tissues (Sarff \& Gorski 1971), this control seems to occur in an inverse manner in CNS (Zhou et al. 1995).

As expected, higher progesterone levels were observed in metestrus (as a consequence of luteal secretion). In proestrus, although no significant difference in progesterone levels was observed among the times studied, the clear tendency toward an increase in the afternoon probably indicates the beginning of follicular secretion which coincides with the LH surge and reaches its maximum after the LH surge in late proestrus (Smith et al. 1975). These plasma progesterone levels may regulate PR expression in LC since the lowest and the highest plasma progesterone levels observed in diestrus and metestrus respectively were accompanied by the highest and lowest expression of PR in LC neurons, correspondingly. Similarly, the clear tendency toward a gradual increase in plasma progesterone levels during proestrus was accompanied by a gradual decrease in PR expression. Thus, one may suggest that PR synthesis is down- or up-regulated by its ligand. In addition, PR expression also seems to be regulated by $\alpha E R$ since the profile of PR expression in LC neurons from metestrus to proestrus followed that of $\alpha$ ER.

It should be noted that estradiol increases noradrenergic turnover before and during the proestrus LH surge in several brain areas, including the POA and median eminence (Rance et al. 1981, Mohankumar et al. 1994), and that an increased noradrenergic input to POA is essential for the synthesis as well as for the release of GnRH (Herbison 1997). In LC neurons, estradiol stimulates gene expression of $\mathrm{TH}$ and dopamine beta hydroxylase (Serova et al. 2002), probably by acting through $\alpha E R$. Besides, it is well established that estradiol induces PRs synthesis in CNS, and that their activation is critical for the LH surge occurrence, since it is blocked by RU-486 administration (Tebar et al. 1998).

Consequently, since we have previously shown that noradrenaline of LC neurons plays an important role in 
GnRH release and gonadotropin surges (AnselmoFranci et al. 1997, Helena et al. 2002), we may hypothesize that estradiol would act in LC $\alpha$ ER-ir cells in order to increase the synthesis of noradrenaline and PRs during the late follicular phase. Subsequently the rising progesterone of proestrus would induce the noradrenaline release, which would induce $\mathrm{GnRH}$, and consequently gonadotropin release. In fact we have shown an increase of FOS expression in LC during proestrus afternoon (Martins-Afferri et al. 2003), which may represent an increase in noradrenaline release in POA, which is required for the release of these hormones.

Estrus Interestingly, on estrus day, the number of aER-ir cells of LC increased, while the number of PR-ir cells decreased, both gradually. We assume that this variation is not related to the variation in gonadotropins or estradiol secretion, since the concentrations of these hormones are constant during this period. However, this result seems to be quite interesting if correlated with prolactin secretion. We have demonstrated that an acute and robust increase in prolactin secretion occurs in the afternoon of estrus (between 15:00 and 17:00 h) in female rats (Szawka \& Anselmo-Franci 2004). Since estradiol is the main hormone inducing prolactin secretion (Freeman et al. 2000) and estradiol concentrations during estrus are constant, an increased number of LC $\alpha E R$-ir neurons by the time of the prolactin surge on estrus day may represent a mechanism to render this nucleus more sensitive to the positive action of estradiol on prolactin secretion. On the other hand, the precise role of progesterone in the secretion of prolactin is not clear. Progesterone is able to advance and amplify the prolactin surge in a time- and dose-dependent manner (Caligaris et al. 1974, Yen \& Pan 1998). In addition, progesterone has been reported to be responsible for the plateau aspect of the proestrus prolactin surge (Arbogast \& Ben-Jonathan 1990). Since progesterone concentrations are high in the afternoon of proestrus and low during estrus, these low plasma progesterone levels, together with the decreased number of LC PR-ir neurons observed in this study, may be responsible for the absence of a plateau phase in the estrus prolactin surge. Thus, even in the absence of alterations in plasma estradiol and progesterone levels, the increase in the number of $\alpha E R$-ir cells and the decrease in the number of PR-ir cells in LC observed here during estrus suggest that LC neurons become more sensitive to the action of estradiol while being less sensitive to progesterone, thus determining not only the occurrence of the secondary prolactin surge, but also its acute shape. Indeed, recent data from our laboratory have demonstrated that LC neurons are essential for the occurrence of this surge, since it is blocked by LC lesion (Poletini et al. 2004).
Preoptic area

Differently from LC, from metestrus to diestrus the number of $\alpha E R$ and PR-ir cells of POA was constant. On proestrus day, although a small increase was observed at $16 \mathrm{~h}$, the number of $\alpha \mathrm{ER}$-ir cells was the lowest in the whole estrous cycle, suggesting that these neurons could be under the control of the same down-regulation mechanism as described for LC neurons. The number of PR-ir cells on proestrus day was similar to that of metestrus and diestrus, except for an increase observed at $16 \mathrm{~h}$. In fact a higher content of $\mathrm{PR}$ in POA on the day of proestrus has been demonstrated (McGinnis et al. 1981). Interestingly, the reduced number of $\alpha E R-i r$ cells found in POA on proestrus day did not cause a decrease in the number of PR-ir cells. Thus, one may hypothesize that the higher estradiol levels observed on this day may compensate for the lower $\alpha$ ER synthesis, thus maintaining PR expression constant. The fact that both receptors presented an increased expression at $16 \mathrm{~h}$ of proestrus afternoon, even without significant changes in estradiol levels, suggests that this pattern may be driven by mechanisms, other than hormonal plasma levels, that are triggered at this critical time of the occurrence of gonadotropin surges.

In the afternoon of estrus, as observed in LC, an increase in the number of $\alpha E R$-ir cells was observed in POA. This increased number of $\alpha E R$-ir cells supports data reported by Shughrue and colleagues (Shughrue et al. 1992), who demonstrated that the content of ER mRNA in POA is high on the afternoon of estrus. As discussed for LC, this finding may be related to the occurrence of the secondary prolactin peak. Indeed, POA neurons have been implicated in the control of prolactin secretion since lesion of this area blocks the prolactin peak induced by estradiol in ovariectomized rats (Pan \& Gala 1985), and electric stimulation of POA increases prolactin secretion in male rats (Colombo 1984).

Thus, although expressive variations on $\alpha \mathrm{ER}$ and $\mathrm{PR}$ expression were observed in LC, these expressions were practically constant through the whole estrous cycle in POA, with minor variations in a few periods. One possibility to explain these different results could be that while LC is almost exclusively constituted by noradrenergic neurons, POA presents several neuronal phenotypes, including neurons that could exert excitatory or inhibitory roles on GnRH release. Consequently, once we did not access the phenotype of the POA neurons expressing $\alpha \mathrm{ER}$ and $\mathrm{PR}$, it is possible that during the estrous cycle a decreased expression of these receptors in inhibitory neurons occurs, which was accompanied by an increased expression in excitatory neurons or vice-versa. Thus, these possible opposite variations would mask real changes in the receptors expression.

In summary, the present data demonstrate that LC neurons do express $\alpha \mathrm{ER}$ and $\mathrm{PR}$, and these expressions fluctuate throughout the estrous cycle in a more variable 
way than observed for POA neurons. In addition, the results suggest that LC may be a primary temporal structure signaling the genesis of hormonal surges, playing an important role in the occurrence of the secondary prolactin peak. Thus, the expression of $\alpha \mathrm{ER}$ and $\mathrm{PR}$ in LC and POA neurons seems to be regulated by complex and distinct factors that act in a coordinated manner to guarantee adequate endocrine and/or behavioral responses for the success of reproduction.

\section{Acknowledgements}

The authors would like to thank Ms Rute A Freitas Marcon, Sonia A Zanon and Ariana Mathias Fernandes for technical support.

\section{Funding}

This study was supported by FAPESP, CNPq, CAPES and CREST Project of JPST. The authors declare that there is no conflict of interest that would prejudice the impartiality of this scientific work.

\section{References}

Anselmo-Franci JA, Franci CR, Krulich L, Antunes-Rodrigues J \& McCann SM 1997 Locus coeruleus lesions decrease norepinephrine input into the medial preoptic area and medial basal hypothalamus and block the LH, FSH and prolactin preovulatory surge. Brain Research 767 289-296.

Anselmo-Franci JA, Rocha-Barros VM, Franci CR \& McCann SM 1999 Locus ceruleus lesions block pulsatile LH release in ovariectomized rats. Brain Research 833 86-92.

Arbogast LA \& Ben-Jonathan N 1990 The preovulatory prolactin surge is prolonged by a progesterone-dependent dopaminergic mechanism. Endocrinology 126 246-252.

Bauer-Dantoin AC, Tabesh B, Norgle JR \& Levine JE 1993 RU486 administration blocks neuropeptide $\mathrm{Y}$ potentiation of luteinizing hormone (LH)-releasing hormone-induced LH surges in proestrous rats. Endocrinology 133 2418-2423.

Blaustein JD \& Turcotte JC 1989 Estradiol-induced progestin receptor immunoreactivity is found only in estrogen receptorimmunoreactive cells in guinea pig brain. Neuroendocrinology 49 454-461.

Butler JA, Sjoberg M \& Coen CW 1999 Evidence for oestrogen receptor alpha-immunoreactivity in gonadotrophin-releasing hormone-expressing neurones. Journal of Neuroendocrinology $11331-335$.

Caligaris L, Astrada JJ \& Taleisnik S 1974 Oestrogen and progesterone influence on the release of prolactin in ovariectomized rats. The Journal of Endocrinology 60 205-215.

Chappell PE, Lydon JP, Conneely OM, O’Malley BW \& Levine JE 1997 Endocrine defects in mice carrying a null mutation for the progesterone receptor gene. Endocrinology 138 4147-4152.

Colombo JA 1984 Dissociation of prolactin and LH release responses after stimulation within the preoptic-suprachiasmatic region in male rats. Experimental and Clinical Endocrinology 84 228-234.
Curran-Rauhut MA \& Petersen SL 2002 The distribution of progestin receptor mRNA in rat brainstem. Brain Research. Gene Expression Patterns 1 151-157.

Everett JW 1948 Progesterone and estrogen in the experimental control of ovulation time and other features of estrous cycle in the rat. Endocrinology 43 389-405.

Foote SL, Bloom FE \& Aston-Jones G 1983 Nucleus locus coeruleus: new evidence of anatomical and physiological specificity. Physiological Reviews 63 844-914.

Fox SR, Harlan RE, Shivers BD \& Pfaff DW 1990 Chemical characterization of neuroendocrine targets for progesterone in the female rat brain and pituitary. Neuroendocrinology 51 276-283.

Franci JA \& Antunes-Rodrigues J 1985 Effect of locus ceruleus lesion on luteinizing hormone secretion under different experimental conditions. Neuroendocrinology 41 44-51.

Freeman ME, Kanyicska B, Lerant A \& Nagy G 2000 Prolactin: structure, function, and regulation of secretion. Physiological Reviews 80 1523-1631.

Greco B, Allegretto EA, Tetel MJ \& Blaustein JD 2001 Coexpression of ER beta with ER alpha and progestin receptor proteins in the female rat forebrain: effects of estradiol treatment. Endocrinology 142 5172-5181.

Grzanna R \& Molliver ME 1980 The locus coeruleus in the rat: an immunohistochemical delineation. Neuroscience 5 21-40.

Haywood SA, Simonian SX, van der Beek EM, Bicknell RJ \& Herbison AE 1999 Fluctuating estrogen and progesterone receptor expression in brainstem norepinephrine neurons through the rat estrous cycle. Endocrinology 140 3255-3263.

Helena CV, Franci CR \& Anselmo-Franci JA 2002 Luteinizing hormone and luteinizing hormone-releasing hormone secretion is under locus coeruleus control in female rats. Brain Research 955 245-252.

Herbison AE 1997 Noradrenergic regulation of cyclic GnRH secretion. Reviews of Reproduction 2 1-6.

Herbison AE 1998 Multimodal influence of estrogen upon gonadotropin-releasing hormone neurons. Endocrine Reviews 19 302-330.

Herbison AE \& Theodosis DT 1992 Localization of oestrogen receptors in preoptic neurons containing neurotensin but not tyrosine hydroxylase, cholecystokinin or luteinizing hormone-releasing hormone in the male and female rat. Neuroscience 50 283-298.

Herbison AE \& Pape JR 2001 New evidence for estrogen receptors in gonadotropin-releasing hormone neurons. Frontiers in Neuroendocrinology 22 292-308.

Herbison AE, Horvath TL, Naftolin F \& Leranth C 1995 Distribution of estrogen receptor-immunoreactive cells in monkey hypothalamus: relationship to neurones containing luteinizing hormone-releasing hormone and tyrosine hydroxylase. Neuroendocrinology 61 1-10.

Heritage AS, Stumpf WE, Sar M \& Grant LD 1980 Brainstem catecholamine neurons are target sites for sex steroid hormones. Science 207 1377-1379.

Kalra SP 1985 Catecholamine involvement in preovulatory LH release: reassessment of the role of epinephrine. Neuroendocrinology 40 139-144.

Krey LC, Tyrey L \& Everett JW 1973 The estrogen-induced advance in the cyclic LH surge in the rat: dependency on ovarian progesterone secretion. Endocrinology 93 385-390.

Kuiper GG, Enmark E, Pelto-Huikko M, Nilsson S \& Gustafsson JA 1996 Cloning of a novel receptor expressed in rat prostate and ovary. PNAS 93 5925-5930.

Kuiper GG, Carlsson B, Grandien K, Enmark E, Haggblad J, Nilsson S \& Gustafsson JA 1997 Comparison of the ligand binding specificity and transcript tissue distribution of estrogen receptors alpha and beta. Endocrinology 138 863-870.

Laflamme N, Nappi RE, Drolet G, Labrie C \& Rivest S 1998 Expression and neuropeptidergic characterization of estrogen 
receptors (ERalpha and ERbeta) throughout the rat brain: anatomical evidence of distinct roles of each subtype. Journal of Neurobiology 36 357-378.

Levine JE \& Ramirez VD 1980 In vivo release of luteinizing hormone-releasing hormone estimated with push-pull cannulae from the mediobasal hypothalami of ovariectomized, steroid-primed rats. Endocrinology 107 1782-1790.

Levine JE \& Ramirez VD 1982 Luteinizing hormone-releasing hormone release during the rat estrous cycle and after ovariectomy, as estimated with push-pull cannulae. Endocrinology 111 1439-1448.

Lubahn DB, Moyer JS, Golding TS, Couse JF, Korach KS \& Smithies O 1993 Alteration of reproductive function but not prenatal sexual development after insertional disruption of the mouse estrogen receptor gene. PNAS 90 11162-11166.

MacLusky NJ \& McEwen BS 1978 Oestrogen modulates progestin receptor concentrations in some rat brain regions but not in others. Nature 274 276-278.

Martins-Afferri MP, Ferreira-Silva IA, Franci CR \& Anselmo-Franci JA 2003 LHRH release depends on Locus Coeruleus noradrenergic inputs to the medial preoptic area and median eminence. Brain Research Bulletin 61 521-527.

McGinnis MY, Krey LC, MacLusky NJ \& McEwen BS 1981 Steroid receptor levels in intact and ovariectomized estrogen-treated rats: an examination of quantitative, temporal and endocrine factors influencing the efficacy of an estradiol stimulus. Neuroendocrinology 33 158-165.

Mitra SW, Hoskin E, Yudkovitz J, Pear L, Wilkinson HA, Hayashi S, Pfaff DW, Ogawa S, Rohrer SP, Schaeffer JM et al. 2003 Immunolocalization of estrogen receptor beta in the mouse brain: comparison with estrogen receptor alpha. Endocrinology 144 2055-2067.

Moffatt CA, Rissman EF, Shupnik MA \& Blaustein JD 1998 Induction of progestin receptors by estradiol in the forebrain of estrogen receptor-alpha gene-disrupted mice. Journal of Neuroscience 18 9556-9563.

Mohankumar PS, ThyagaRajan S \& Quadri SK 1994 Correlations of catecholamine release in the medial preoptic area with proestrous surges of luteinizing hormone and prolactin: effects of aging. Endocrinology 135 119-126.

Neill JD, Freeman ME \& Tillson SA 1971 Control of the proestrus surge of prolactin and luteinizing hormone secretion by estrogens in the rat. Endocrinology 89 1448-1453.

Okamura H, Yamamoto K, Hayashi S, Kuroiwa A \& Muramatsu M 1992 A polyclonal antibody to the rat oestrogen receptor expressed in Escherichia coli: characterization and application to immunohistochemistry. Journal of Endocrinology 135 333-341.

Osterburg HH, Telford NA, Morgan DG, Cohen-Becker I, Wise PM \& Finch CE 1987 Hypothalamic monoamines and their catabolites in relation to the estradiol-induced luteinizing hormone surge. Brain Research 409 31-40.

Pan JT \& Gala RR 1985 Central nervous system regions involved in the estrogen-induced afternoon prolactin surge. II. Implantation studies. Endocrinology 117 388-395.

Papka RE, Srinivasan B, Miller KE \& Hayashi S 1997 Localization of estrogen receptor protein and estrogen receptor messenger RNA in peripheral autonomic and sensory neurons. Neuroscience 79 1153-1163.

Park OK \& Ramirez VD 1989 Spontaneous changes in LHRH release during the rat estrous cycle, as measured with repetitive push-pull perfusions of the pituitary gland in the same female rats. Neuroendocrinology $\mathbf{5 0}$ 66-72.

Paxinos G \& Watson C 1998 The rat brain in stereotaxic coordinates. New York: Academic Press.

Pickel VM, Joh TH \& Reis DJ 1975 Ultrastructural localization of tyrosine hydroxylase in noradrenergic neurons of brain. PNAS 72 659-663.
Poletini MO, Szawka RE, Franci CR \& Anselmo-Franci JA 2004 Role of the locus coeruleus in the prolactin secretion of female rats. Brain Research Bulletin 63 331-338.

Rance N, Wise PM, Selmanoff MK \& Barraclough CA 1981 Catecholamine turnover rates in discrete hypothalamic areas and associated changes in median eminence luteinizing hormone-releasing hormone and serum gonadotropins on proestrus and diestrous day 1. Endocrinology 108 1795-1802.

Sarff M \& Gorski J 1971 Control of estrogen binding protein concentration under basal conditions and after estrogen administration. Biochemistry 10 2557-2563.

Serova L, Rivkin M, Nakashima A \& Sabban EL 2002 Estradiol stimulates gene expression of norepinephrine biosynthetic enzymes in rat locus coeruleus. Neuroendocrinology 75 193-200.

Shirley B, Wolinsky J \& Schwartz NB 1968 Effects of a single injection of an estrogen antagonist on the estrous cycle of the rat. Endocrinology 82 959-968.

Shu SY, Ju G \& Fan LZ 1988 The glucose oxidase-DAB-nickel method in peroxidase histochemistry of the nervous system. Neuroscience Letters 85 169-171.

Shughrue PJ, Bushnell CD \& Dorsa DM 1992 Estrogen receptor messenger ribonucleic acid in female rat brain during the estrous cycle: a comparison with ovariectomized females and intact males. Endocrinology 131 381-388.

Shughrue PJ, Lane MV \& Merchenthaler I 1997 Comparative distribution of estrogen receptor-alpha and -beta mRNA in the rat central nervous system. The Journal of Comparative Neurology 388 507-525.

Smith MS, Freeman ME \& Neill JD 1975 The control of progesterone secretion during the estrous cycle and early pseudopregnancy in the rat: prolactin, gonadotropin and steroid levels associated with rescue of the corpus luteum of pseudopregnancy. Endocrinology 96 219-226.

Swanson LW \& Hartman BK 1975 The central adrenergic system. An immunofluorescence study of the location of cell bodies and their efferent connections in the rat utilizing dopamine-beta-hydroxylase as a marker. The Journal of Comparative Neurology 163 467-505.

Szawka RE \& Anselmo-Franci JA 2004 A secondary surge of prolactin on the estrus afternoon. Life Sciences 75 911-922.

Tebar M, Ruiz A, Gonzalez D, Hernandez G, Alonso R \& Sanchez-Criado JE 1998 Effect of RU486 injected on proestrous morning on LHRH, LH and 17 beta-estradiol secretion during the estrous cycle in rat. Journal of Physiology and Biochemistry 54 91-97.

Tima L \& Flerko B 1974 Ovulation induced by norepinephrine in rats made anovulatory by various experimental procedures. Neuroendocrinology 15 346-354.

Traish AM \& Wotiz HH 1990 Monoclonal and polyclonal antibodies to human progesterone receptor peptide-(533-547) recognize a specific site in unactivated $(8 \mathrm{~S})$ and activated $(4 \mathrm{~S})$ progesterone receptor and distinguish between intact and proteolyzed receptors. Endocrinology 127 1167-1175.

Warembourg M, Jolivet A \& Milgrom E 1989 Immunohistochemical evidence of the presence of estrogen and progesterone receptors in the same neurons of the guinea pig hypothalamus and preoptic area. Brain Research $4801-15$.

Watson RE, Jr., Wiegand SJ, Clough RW \& Hoffman GE 1986 Use of cryoprotectant to maintain long-term peptide immunoreactivity and tissue morphology. Peptides 7 155-159.

Weiland NG, Orikasa C, Hayashi S \& McEwen BS 1997 Distribution and hormone regulation of estrogen receptor immunoreactive cells in the hippocampus of male and female rats. The Journal of Comparative Neurology 388 603-612.

Wright DE \& Jennes L 1993 Origin of noradrenergic projections to GnRH perikarya-containing areas in the medial septum-diagonal band and preoptic area. Brain Research 621 272-278. 
Yen SH \& Pan JT 1998 Progesterone advances the diurnal rhythm of tuberoinfundibular dopaminergic neuronal activity and the prolactin surge in ovariectomized, estrogen-primed rats and in intact proestrous rats. Endocrinology 139 1602-1609.

Zhou Y, Shughrue PJ \& Dorsa DM 1995 Estrogen receptor protein is differentially regulated in the preoptic area of the brain and in the uterus during the rat estrous cycle. Neuroendocrinology 61 276-283.
Received 31 October 2005

Accepted 8 November 2005

Made available online as an Accepted Preprint 22 November 2005 